\title{
INITIATING THE IMPLEMENTATION OF BASIC PRINCIPLES OF GOOD COOPERATIVE GOVERNANCE IN THE VALUE CHAIN FINANCIAL MANAGEMENT AT THE COOPERATIVE OF FAJAR SURYA MANDIRI IN THE DISTRICT OF SIMALUNGUN
}

\author{
Revita Yuni $^{1}$, Roza Thohiri ${ }^{1}$, Pebri Hastuti ${ }^{1}$, Putri Sari M. J. Silaban ${ }^{1}$ \\ ${ }^{1}$ Faculty of Economics, Universitas Negeri Medan, Medan, Indonesia \\ *Corresponding Author: revitayuni25@gmail.com
}

\begin{abstract}
This applied research focuses on the initiative to develop a model of value chain financial management that further enabling the implementation of cooperative governance in the whole aspect of business managed by the cooperative of Fajar Surya Mandiri located at the village of Bandar Jawa, of subdistrict of Bandar in the district of Simalungun at the Province of Sumatera Utara, Indonesia. More specifically, the application internal control system was introduced in cooperative business management activities that are mainly engaged with poultry and freshwater pond fish productions. The management was facilitated with the technical knowledge on the preparation of financial statements based on Financial Accounting Standard of Entities without Public Accountability as well as guiding staffs in the preparation of Standard Operating Procedure (SOP) for accounting and finance related activities and developing a website that provides profile and products of the cooperative. Applied outcomes of this community service engagement consisted of SOP and guidelines on the preparation of the financial statements of the cooperative as well as the company website and social media accounts for relevant marketing purposes.
\end{abstract}

Keywords: Applied Research, Cooperative, SOP of Financial Reporting, Value Chain Financial Management, Simalungun.

\section{INTRODUCTION}

Cooperatives are one of the economic organizations that have space to move and business opportunities that concern the interests of the people's economic life. Thus, progress and development of cooperatives increasingly play a role in the national economy. The role and function of cooperatives are not only limited to economic activity but also as a manifestation of collective spirit, togetherness and the principle of justice rooted in our society, namely mutual cooperation. In addition, the cooperative business model is a manifestation of our basic constitution, namely the 1945 Constitution paragraph 1 states that the Economy is structured as a joint effort on the principle of kinship. It is our collective duty and all elements of the nation to continue to advance the operational sector in Indonesia.

At present cooperatives in Indonesia are faced with two main challenges. First, namely improving the quality of institutions and management of cooperative units. Secondly, the cooperative unit also needs to continue to improve competitiveness and not only play a role at the national level but also world class. Through strengthening these two things will increase the number of cooperative units capable of acting in the ASEAN region as well as in the country will further strengthen social capital (social capital). In a number of Scandinavian countries, the cooperative membership network proved to be able to reduce the emergence of the risk of social conflict because of the spirit of togetherness, kinship, and justice that binds individuals and members of business entities.

In terms of institutions, the presence of Law No. 17 of 2012 has provided a basis for strengthening the management and progress of cooperatives in Indonesia. The principles are regulated from the establishment, management, supervision to the role of the Indonesian Cooperative Council and the Government to enhance the strategic role of cooperatives. As a business unit, cooperatives need support to be able to be more competitive and managed in a modern manner based on the principle of togetherness and kinship. So that cooperatives will be able to play an important role such as other forms of business such as BUMN and the Company.

Through institutional strengthening and renewal of legislation that regulates Cooperatives in Indonesia, it is expected that in the future the Cooperative will play a much more strategic role in the national economic system. A number of developed countries such as the United States, Japan, France, Britain, and Spain can be our benchmarks for advancing the cooperative sector. Even according to International Co-Operative Alliance (ICA) there are a number of countries where the contribution of cooperatives in GDP is quite large and can even be above 10 percent such as Finland, 
Switzerland, New Zealand, Norway, and the Netherlands. The cooperative sector in Europe also succeeded in placing cooperatives as joint business entities that play an important role in the country's economy.

Strengthening cooperatives in the national economic system is also carried out through the development of public awareness. Through the Cooperative Conscious Community Movement, it has been launched since 2010 and to date has contributed to an increase in the number of cooperatives in the country. According to data from the Ministry of SMEs and Cooperatives, there was an increase of 17.4 percent of the number of cooperative units from 2009 which was recorded at 170,411 units to 200,808 units in July 2013. While in terms of the total membership, there was an increase of 18.8 percent from 2009 registered members 29.2 million people increased to 34.7 million people. With such a large number of members, the cooperative business volume in mid-2013 has reached Rp. 115.2 trillion or a double-digit growth of 12.09 percent from 2012. The increase in numbers both in terms of cooperative units, membership numbers, and business volume show that cooperatives have played a strategic role in the national economic system.

The government continues to encourage the revitalization of the role and rise of national cooperatives to realize the quality and equitable economic development. Through a number of programs (including providing capital access through KUR and LPDB), the Government facilitates cooperative growth and development so that it can become a strong business entity and contribute greatly to the ongoing development process. In addition, intensification and extension of counseling and management training and cooperative control systems also need to be improved. This is because there are still many cooperatives in Indonesia in non-active situations but have very good business potential.

Therefore, the basis of this community service activity is as an effort to provide counseling, training, and assistance regarding business management and designing a good internal control system for cooperatives in Simalungun Regency, especially the Fajar Surya Mandiri Production Cooperative. The cooperative is headed by Mr. Dedi Kurniawan, located in Bandar Jawa Village, Bandar Subdistrict, Simalungun Regency, which has been operating since June 2017. Currently, its economic activities are still centered on savings and loan activities among members and purchasing chicken and catfish feed to support livestock business and fisheries managed by 14 (fourteen) members. In terms of financial performance, based on the information described in the financial statements as of December 31, 2017, the cash balance of the Fajar Surya Mandiri Production Cooperative amounts to Rp. 3,803,000, -. This is quite vulnerable considering that the nominal is only able to finance $1 / 4$ of the total production costs related to the livestock and fisheries business of its members.

In addition, from the search results to the field, several factors that have caused unfavorable conditions in the Fajar Surya Mandiri Production Cooperative include:

1) The quality of human resources both members, administrators, managers, and supervisors are still doubtfully marked by a large number of human resources who do not have good skills and weak cooperative management. The existence of cooperatives that are widely available in remote villages has members who are not supported by sufficient education so that the existing managers and managers are unable to collect and mobilize the various resources needed to develop cooperatives. This lack of education also eventually caused many KUD (Village Cooperative Units) to go bankrupt because of the lack of professionalism of cooperative management both in the business management system, in terms of human and financial resources. Cooperative management must be directed at the strategic orientation and the cooperative movement must have people who are able to collect and mobilize the various resources needed to take advantage of business opportunities. Therefore the cooperative must be careful in choosing the management and managers so that the established business entity will develop well.

2) Lack of supervision of cooperatives. The scope and extent of cooperatives as an economic unity as an economic entity will be increasingly complex so that the range of control between management and implementation is increasingly distant. To be able to control cooperative operations, management requires a tool that can control cooperative activities. To find out whether internal control is going well, management needs to carry out continuous internal checks on the internal control structure. Internal inspection in cooperative organizations is known as the Supervisory Board. The establishment of the Supervisory Board as an internal supervisor is regulated in Articles 38, 39 and 40 of the Cooperative Law, while external supervision can be carried out by the public and the government, especially the regional government. But nowadays supervision of cooperatives is very lacking both internally and externally. This is marked by the many inactive cooperatives and the number of cooperatives that run only as a cover for fraud.

3) The internal control system at the Fajar Surya Mandiri Production Cooperative is still weak, causing various fraud risks to occur because the dynamics of personnel in carrying out management processes and accounting media can be misused at any time by anyone involved in the activity. Thus, cooperative assets cannot be protected, and accounting data, financial information, and reports produced have not been very careful and thorough.

In addition, one of the trigger factors for the occurrence of cooperative management problems in terms of management and finance is still experiencing these obstacles, namely the management of cooperatives has not been carried out professionally as a private company. The management of cooperatives is chosen based on the trust of the members of 
the cooperative towards the elected management, and there are still many cooperative managers who do not yet have sufficient knowledge of business management because they have no economic background. When these conditions are faced with a real business, what is done to manage cooperatives is not optimal, this affects the ability of cooperatives to survive in their business environment. Relatively large enough to encourage the creation of business growth (success) that can be measured by an increase in asset quantity business, services, income, Remaining Business Results (SHU), savings and loans, wealth, own capital so that it can play a more strategic role in the national economic system. Specifically, to deal with the era of free competition, there needs to be prepared both in terms of soft skills and infrastructure through increased capacity in terms of business management and the design of a good internal control system in order to win the competition in the global market.

\subsection{Special Problems and Priority Problems}

The specific problems faced by the Fajar Surya Mandiri Production Cooperative are:

1) The quality of human resources both members, administrators, managers, and supervisors are still doubtfully marked by a large number of human resources who do not have good skills and weak cooperative management.

2) Inadequate internal control system so that it is not biased to identify potential occurrences of irregularities as a result of weaknesses and human nature which are: inaccurate, negligent, fraudulent, dishonest and others.

Based on the description of the specific problems above, it can be seen the priority problems that will be resolved in this PKM activity. The priority issue in question emphasizes the importance of implementing business management and a good internal control system in the activities of the Fajar Surya Mandiri Production Cooperative. The success or failure of a cooperative depends on the quality and work in the field of management and internal control systems. As a business organization or company that is managed on the basis of family principles, cooperatives must adhere to the principles of sound, transparent and accountable management and be fair in achieving common goals.

Various studies have shown that safeguarding the wealth of cooperatives is still vulnerable, and the use of wealth is also a lot that is not right so that cooperatives lack the trust of various parties. To be able to overcome this, the management requires management tools as a controlling media, namely internal control. Internal control is a system that is built through the organization and mechanism of operations within the cooperative, so that it is attached to every activity carried out by each person in the cooperative, starting from supervisors, managers, assistant managers or section heads and employees. Building self-confidence and planting competencies, as well as responsibility for the work to produce the best, is one of the keys to the successful implementation of internal control. With the implementation of adequate internal controls, it is expected that the security of cooperative assets and efficient management and effectiveness in achieving objectives will be more secure so that the trust of the parties to the cooperative can be developed.

\subsection{Profile of the Involved Partners}

The Fajar Surya Mandiri Production Cooperative is located on Jalan Huta II Kampung Gunung, Bandar Jawa Village, Bandar District, Simalungun Regency. The cooperative is led by Mr. Dedi Kurniawan who is a driving force figure in chicken farming and catfish farming in the local village. This cooperative has 14 active members with the same business scope. The form of cooperation offered by this cooperative is cooperation between the core companies and plasma farmers (breeders). Cooperatives as business entities act as providers of sapronak (Chicken Seed / DOC, Catfish Seeds, Feed, Vaccines, and Medication) while plasma farmers are responsible for carrying out cultivation to become broilers and catfish which are ready for harvest.

The Fajar Surya Mandiri Production Cooperative's organizational structure consists of the Management Board, the Supervisory Board, and the Management. However, none of the position holders in the intended position had an accounting and financial background. Except for Mr. Dedi Kurniawan who has a Bachelor of Fisheries diploma from one of the private universities in Medan; the other members are from high school and junior high school education.

\section{OUTPUTS SOLUTION AND TARGETS}

\subsection{The solution to Resolving Priority Problems}

The implementing team has designed 3 (three) alternative solutions to solve the priority problems described in section 1.2. The priority problem matrix and the intended target are described in table 2 as follows:

Table 1. Matrix of Priority and Solution Problems.

\begin{tabular}{|c|c|c|}
\hline No & Priority Issues & Alternative Solutions \\
\hline 1 & $\begin{array}{lll}\begin{array}{l}\text { Improvement } \\
\text { cooperative } \\
\text { management. }\end{array} & \begin{array}{l}\text { of business } \\
\text { management }\end{array} & \begin{array}{l}\text { and } \\
\text { and }\end{array} \\
& & \end{array}$ & $\begin{array}{l}\text { - Assistance in the preparation of financial accounting standards } \\
\text { - Entities without Public Accountability (SAK-ETAP) } \\
\text { - Assistance in the preparation of Cooperative Accounting } \\
\text { Manual Standard Operating Procedure (SOP) }\end{array}$ \\
\hline
\end{tabular}


$2 \quad$ Publication of profiles and financial and non-financial activities of the Fajar Surya Mandiri Production Cooperative online using a website
Assistance in making and operating Cooperative websites with the https://blogspot.co.id platform and/or other social media (Facebook and Instagram)

\section{IMPLEMENTATION METHOD}

\subsection{Method of Implementation of Activities}

The method of activities in the community service program (PKM) is counseling, training and co-operative assistance in managing the business and designing an internal control system. In this case, the head of the program and its members act as a mediation.

1) Method of Implementation of PKM

The implementation of the community service program is carried out in stages:

a. Informing about the implementation of activities to the management of the Fajar Surya Mandiri Production cooperative.

b. Providing counseling and training on the benefits and ways to manage a good business for cooperatives.

c. Providing counseling and training on the benefits and ways of designing reliable SPI for cooperatives through the preparation of SAK-ETAP-based Financial Report SOP manuals.

2) Evaluation of Success

The results received from this activity were re-analyzed by the implementers of this PKM activity to determine the level of success of activities and deficiencies and things that must be done again so that the objectives of the activities can be carried out properly and provide practical benefits to all parties involved in business management training and designing a reliable internal control system for Fajar Surya Mandiri Production cooperatives specifically, and other cooperatives in Simalungun Regency.

\subsection{Approach Method for Resolving Problems According to the Agreement}

Figure 1 presents a graphical illustration of the approach method for solving priority issues that have been agreed upon with partners.

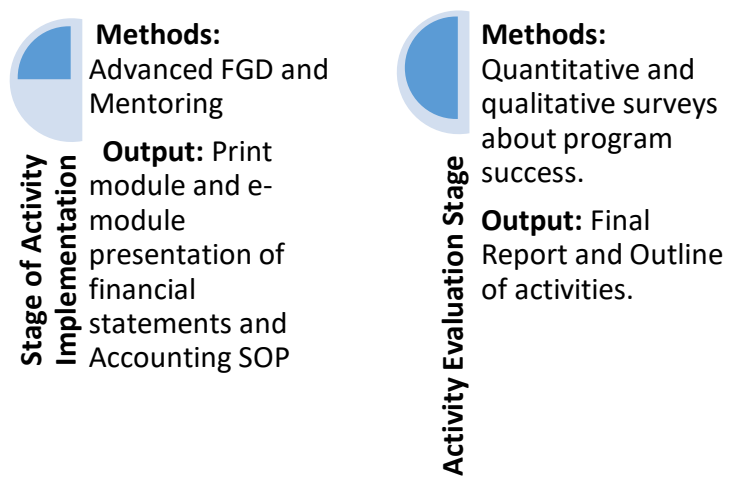

Figure 1. Approach Method for Each Stage of Activity Implementation.

\subsection{Partner Participation in Program Implementation}

The participation of the Fajar Surya Mandiri Production Cooperative is in the form of:

a. Provision of information and facilities for program implementation

b. Present and actively participate in the application of the solutions set out in Table 3 .

c. Follow up on the solution in question independently after the implementation of the activity with or without further assistance from the team of proposers/implementers of the activity.

\section{RESULTS AND OUTPUT ACTIVITIES}

\subsection{Activity Results}

As explained earlier, the focus of the implementation of this PKM is to improve governance at the Fajar Surya Mandiri Production Cooperative in Simalungun District. The activity takes place for 2 days (17-18 September 2018). The realization of the program's implementation on the first day began with the presentation of the importance of cooperative governance referring to SAK ETAP based on computerization through Microsoft Word and Excel applications in the Windows operating system. The activity on the following day emphasizes the assistance and training of updating data which includes: Member Data, Member Savings Data, Member Loan Data, Deposits Data from Institutions / Units; Close Book Balance Sheet that is set up following the closing year of the booking period, which is December 31. The 10 participants from the Fajar Surya Mandiri Production Cooperative in SImalungun Regency were relatively able to take part in the program and gave achievements according to the expected results, namely the implementation of the intended database update until the 18 September 2018 period. Chair of the Fajar 
Surya Mandiri Production Cooperative as validator also benefited from the supply of real-time financial information so that it could become the basis for further decision-making specifically as a material for the participation of members and administrators related to the use of cooperative funds to finance the operational activities of the Fajar Surya Mandiri Production Cooperative.

The financial reporting and administration system designed in this activity is a system that is expected to be able to overcome the problems faced by partners, especially in terms of the administrative management of routine purchases and expenditures of the Fajar Surya Mandiri Production Cooperative. So that in addition to focusing on supporting data updating competencies, this PKM also focuses on solving the focus of problems in the printing process of various transaction proofs. The resulting system is designed simply with a Windows-based interface. This simple system operation has been able to cut service time needed and save excessive use of office stationery because it has been summarized by the use of printing machines. If previously a member wanted to find out the amount of loan and/or savings needed for approximately 5-8 minutes and processing transaction evidence takes 4-7 minutes, then now it can be done for 1-2 minutes until the printing process. The system has been run on a computer that was donated by the PKM implementation team.

Going forward, it is necessary to design an integrated financial reporting program that can integrate all aspects of the Fajar Surya Mandiri Production Cooperative in real time and connect with the reporting system in the parent area of the Simalungun Regency. In particular, further assistance programs can be directed towards improving the financial administration and reporting system that is able to:

1) Include additional data and documentation such as photos, home addresses, etc. The upgrading of the intended database is also expected to be able to integrate financial data such as the size of the loan, the number of installments, the remaining period of installments, the amount of savings, and so on.

2) Print member data and proof of transactions (saving, paying installments, purchases, sales, payment of operating expenses) in a compact sheet format so that it can create efficiency and economize the optimal use of paper.

\section{CONCLUSION}

Operational mentoring of the reporting system and financial administration is able to overcome the problems faced by the management of the Fajar Surya Mandiri Production Cooperative related to the administration of routine sales and purchases at the institution in question. This activity also focused on operational assistance in the printing process of various relevant transaction proofs in the operational activities of the Fajar Surya Mandiri Production Cooperative. The operating system in question is able to provide efficiency, effectiveness, and economization of the service process and produce output from processed transactions.

To optimize the administrative and financial service processes at the Fajar Surya Mandiri Production Cooperative, a program that integrates financial reporting needs to be built that can integrate all aspects of the Fajar Surya Mandiri Production Cooperative online and real-time specifically connected with the financial reporting system in the district cooperative parent Simalungun. 